\title{
Bacteriological Survey of Feces from Feral Pigeons in Japan
}

\author{
Chikako TANAKA ${ }^{1)}$, Takayuki MIYAZAWA ${ }^{1)}$, Masahisa WATARAI ${ }^{2)}$ and Naotaka ISHIGURO $^{3) *}$ \\ ${ }^{1)}$ Laboratories of Veterinary Public Health and ${ }^{2)}$ Veterinary Microbiology, Obihiro University of Agriculture and Veterinary Medicine, \\ Obihiro 080-8555, and ${ }^{3}$ Laboratory of Food and Environmental Hygiene, Faculty of Applied Biological Sciences, Gifu University, Gifu \\ 501-1193, Japan
}

(Received 9 February 2005/Accepted 18 May 2005)

ABSTRACT. Some public areas in Japan such as parks and gardens can be highly contaminated with pigeon feces. We examined levels of four bacterial contaminations in fecal samples from feral pigeons in 7 prefectures. We isolated Salmonella Typhimurium and $S$. Cerro from 17 (3.9\%) of 436 samples, as well as Mycobacterium spp. including M. avium-intracellulare complex from 29 (19.0\%) of 153 samples. The polymerase chain reaction detected Chlamydia psittaci and C. pecorum in $106(22.9 \%)$ of 463 samples, but $E$. coli O-157 was not isolated from any of the samples. Our results indicate that pigeon feces are a source of several zoonotic agents for birds, animals and humans.

KEY WORDS: feces, pigeon, salmonella.

J. Vet. Med. Sci. 67(9): 951-953, 2005

Pigeons (Columba livia) are widely distributed in urban and rural areas of Japan, and come into close contact with humans in parks, temples, shrines, public gardens and railroad stations. A recent increase in the number of pigeons has raised public health concerns [7]. Pigeons are potential reservoirs for several pathogenic microorganisms, including Chlamydia spp., Salmonella spp. and Cryptococcus. In Japan, $S$. Typhimurium $[5,14,15], C$. psittaci $[3,6,8]$ and Mycobacterium spp. $[10,11]$ have been isolated from feral pigeons and the frequency of Salmonella spp. and Chlamydia spp. is particularly high $[1,2,12]$. The presence of pigeon feces in public parks and railroad stations has contributed to the spread of infectious agents in the environment. We therefore extensively surveyed four pathogens (Salmonella spp., Escherichia coli 0-157, Mycobacterium spp. and Chlamydia spp.) in pigeon feces collected from public areas in Japan from 2003 to 2004.

Fecal samples (fresh or dry composite) were collected from 38 public areas in 7 prefectures (Hokkaido, Tokyo, Kanagawa, Gifu, Aichi, Osaka and Hiroshima) in Japan. Dry samples were placed in polyethylene bags, and fresh samples were placed in $15-\mathrm{m} l$ tubes containing $1 \mathrm{~m} l$ of phosphate-buffered saline.

To isolate Salmonella spp., about 0.5 to $3 \mathrm{~g}$ of fecal samples were cultured in Hajna tetrathionate broth (Eiken, Tokyo, Japan) and then plated on DHL agar (Eiken) and on CHROMagar Salmonella (CHROMagar Microbiology, Paris, France). Salmonella-like isolates on DHL or CHROMagar plates were examined using TSI (Eiken) and LIM (Eiken) media and confirmed by slide and tube agglutination with commercial antisera (Denka Seiken, Tokyo, Japan). To isolate E. coli O-157, about 2 to $3 \mathrm{~g}$ of feces was cultured in mEC broth (Kyokutou, Tokyo, Japan) with novobiocin, and examined using a PATH-STIK KIT (Celsis

\footnotetext{
* Correspondence to: Ishiguro, N., Laboratory of Food and Environmental Hygiene, Faculty of Applied Biological Sciences Gifu University, Gifu, 501-1193, Japan.
}

Lumac, B. V. Landgraaf, The Netherlands). We finally confirmed the presence of $E$. coli $\mathrm{O}-157$ by slide agglutination with a specific antibody (Denka Seiken). To isolate $M y c o-$ bacterium spp. about 1 to $3 \mathrm{~g}$ of fecal samples were mixed with $0.1 \%$ acriflavine and $4 \% \mathrm{NaOH}$, and inoculated on Ogawa slant medium (Nissui, Tokyo, Japan). Colonies on the slants were visualized by Ziehl-Neelsen staining, and Mycobacterium spp. were identified using the DNA-DNA hybridization kit, DDH Mycobacteria (Kyokuto) and by sequencing of 16S rRNA fragment [17]. Total DNA for the polymerase chain reaction (PCR) was extracted from $0.2 \mathrm{~g}$ of pigeon feces using the QIAamp DNA Stool Minikit (QIAGEN, GmbH, Germany). Mycobacterial DNA was extracted from bacterial cells using $1 \%$ sodium dodecyl sulfate and several phenol-chloroform washes. To detect Chlamydia spp., nested PCR amplified the major outer membrane protein (MOMP) fragment using the primers CMGP-1F, CMGP-1R, CMGP-2F and CMGP-2R provided by Dr. H Fukushi of Gifu University. The PCR for Chlamydia spp. started with denaturation at $94^{\circ} \mathrm{C}$ for $5 \mathrm{~min}$, followed by 40 amplification cycles of $94^{\circ} \mathrm{C}$ for $30 \mathrm{sec}, 56^{\circ} \mathrm{C}$ for $30 \mathrm{sec}$ and $72^{\circ} \mathrm{C}$ for $30 \mathrm{sec}$, and ending with final extension at $72^{\circ} \mathrm{C}$ for $7 \mathrm{~min}$. The primers for the first nested PCR were CMGP-1F and CMGP-1R, and those for the second were CMGP-2F and CMGP-2R. The PCR for Mycobacterium spp. was proceeded as described by Springer et al. [17]. To amplify the DNA fragment specific for the $16 \mathrm{~S}$ rRNA of Mycobacterium spp., PCR included primers 264 and 285 [17]. The PCR amplified products from Chlamydia spp. and Mycobacterium spp., were sequenced using an ABI PRISM 310 Genetic Analyzer with the BigDye Terminator Cycle Sequencing Ready Reaction (Applied Biosystems, Foster City, CA). Each bacterium was genetically identified through DNA homology analyses of a nucleotide sequence database using the BLAST algorithms.

Table 1 shows the isolation frequency of Salmonella spp. We identified $S$. Cerro (7 strains), $S$. Typhimurium subsero- 
Table 1. Detection frequency of organisms from pigeon feces

\begin{tabular}{lccccc}
\hline \multirow{2}{*}{ Prefecture } & No. of sites & \multicolumn{4}{c}{ Detection frequency ${ }^{\mathrm{a})}$} \\
\cline { 3 - 6 } & & Salmonella spp. & Mycobacterium spp. & E. coli $0-157$ & ${\text { Chlamydia } \text { spp. }^{\mathrm{b})}}^{\mathrm{b}}$ \\
\hline Hokkaido & 6 & $6 / 30^{\mathrm{c}}$ & $0 / 25$ & $0 / 29$ & $28 / 35^{\mathrm{i})}$ \\
Tokyo & 7 & $1 / 6^{\mathrm{c})}$ & $0 / 25$ & $0 / 12$ & $14 / 23^{\mathrm{i})}$ \\
Kanagawa & 2 & $0 / 3$ & $2 / 2^{\mathrm{g})}$ & $0 / 1$ & $1 / 4^{\mathrm{i})}$ \\
Gifu & 16 & $9 / 276^{\mathrm{d}, \mathrm{e}, \mathrm{f}}$ & $24 / 56^{\mathrm{g}, \mathrm{h})}$ & $0 / 24$ & $41 / 290^{\mathrm{i}, \mathrm{g})}$ \\
Aichi & 4 & $1 / 8^{\mathrm{c})}$ & $1 / 33^{\mathrm{g})}$ & $10 / 14$ & $10 / 81^{\mathrm{i}, \mathrm{k})}$ \\
Osaka & 2 & $0 / 29$ & $2 / 11^{\mathrm{g})}$ & $0 / 27$ & $11 / 29^{\mathrm{i})}$ \\
Hiroshima & 1 & $0 / 1$ & $0 / 1$ & $0 / 1$ & $1 / 1^{\mathrm{i})}$ \\
\hline Total & 38 & $17 / 436$ & $29 / 153$ & $0 / 108$ & $106 / 463$ \\
& & $(3.9 \%)$ & $\left(19.0^{\circ} \%\right)$ & & $(22.9 \%)$ \\
\hline
\end{tabular}

a) No. of positive samples / No. of samples examined. b) Genetical detection by PCR. c) $S$. Typhimurium, d) $S$. Cerro, e) Untypable strain in $\mathrm{O} 4$ group, f) Untypable strain in O8 group, g) $M$. avium-intracellulare complex, h) $M$. terrae, M. gordonae, M. hiberniae, M. szulgai, M. porcinum, M. malmonse or M. selatum, i) C. psittaci, g) C. pecorum (from two samples), k) C. pecorum (from one sample).

Table 2. Longitudinal investigation of Salmonella and Chlamydia spp. at city C in Gifu Prefecture

\begin{tabular}{cllllll}
\hline \multirow{2}{*}{ Species } & \multicolumn{5}{c}{ Detection frequency } \\
\cline { 2 - 7 } & Sep. 2003 & Nov. 2003 & Dec. 2003 & Apr. 2004 & Jul. 2004 & Total \\
\hline Salmonella spp. & $5 / 9^{\mathrm{a})}$ & $0 / 14$ & $3 / 182^{\mathrm{a}, \mathrm{b})}$ & $\left.1 / 33^{\mathrm{c}}\right)$ & $0 / 12$ & $9 / 250$ \\
& $(55.6 \%)$ & $(1.6 \%)$ & $(3.0 \%)$ & $(3.6 \%)$ & $0 \%$ & $(3.6 \%)$ \\
Chlamydia spp. & $11 / 16^{\mathrm{d}, \mathrm{e})}$ & $11 / 11^{\mathrm{d})}$ & $19 / 187^{\mathrm{d})}$ & $0 / 50$ & $0 / 26$ & $41 / 290$ \\
& $(68.8 \%)$ & $(100 \%)$ & $(10.2 \%)$ & $0 \%$ & $(14.1 \%)$ & $(14.1 \%)$ \\
\hline
\end{tabular}

a) $S$. Cerro, b) One untypable strain in O4 group, c) Untypable strain in O8 group, d) Chlamydia psittaci, e) $C$. pecorum (from two samples).

var Copenhagen (8 strains), and untypable strains in serogroups O4 (1 strain) and O8 (1 strain) from 17 isolates $(3.9 \%)$ in 436 fecal samples. $S$. Typhimurium strains were isolated from railroad stations and public parks in Hokkaido (6/30: $20.0 \%$ ), from railroad stations in Tokyo (1/16: $6.3 \%$ ) and from Buddhist temples in Aichi Prefecture (1/81: 1.2\%). $S$. Cerro strains were isolated from railroad stations and public parks in city $\mathrm{C}$ in Gifu Prefecture during a longitudinal survey from September 2003 to July 2004, (Table 2). The isolation frequency of $S$. Cerro was $55.6 \%$ in September 2003 and $1.1 \%$ in December 2003.

All 108 fecal samples examined were negative for $E$. coli O-157 (Table 1).

We found that $19.0 \%(29 / 153)$ of the fecal samples contained Mycobacterium spp. The following Mycobacterium spp. were identified by DNA sequencing and homology analyses: $M$. avium-intracellulare complex (MAC, 10 strains), $M$. terrae (9 strains), M. gordonae (4 strains), $M$. szulgai (2 strains), M. hiberniae (2 strains), M. porcinum (1 strain), and 1 unidentifiable strain (M. malmonse or M. selatum). The MAC strains were detected in the samples from Kanagawa, Gifu, Aichi and Osaka Prefectures (Table 1). Several Mycobacterium strains were predominant in fecal samples from Gifu Prefecture, but the prevalence did not differ between dry and fresh fecal samples from any area. We identified Chlamydia spp in 106 (22.9\%) of 463 fecal samples by nested PCR. C. psittaci (103 strains) and $C$. pecorum ( 3 strains) were confirmed by sequencing the
MOMP fragment (Table 1). C. psittaci was detected in the samples from all 7 prefectures examined. Only three PCR products were identified as $C$. pecorum, and these were from Gifu and Aichi Prefectures. C. psittaci was frequently detected in the fecal samples from a longitudinal survey of city C in Gifu Prefecture (Table 2). The high frequency of C. psittaci continued until Dec. 2003, but had decreased by Apr. 2004.

An important agent of food poisoning in humans is $S$. Typhimurium subserovar Copenhagen [9] found in the present study. This organism has frequently been isolated from pigeons in Japan $[14,15]$. $S$. Cerro has been isolated from chickens in Japan [16], although the serovar has been rarely detected in pigeons. We found $S$. Cerro isolates twice during the survey period. This serovar might spread among pigeons in city $\mathrm{C}$ over a short period. Although food poisoning caused by $S$. Cerro was not recorded in city $\mathrm{C}$ during 2003 , the spread of $S$. Cerro among pigeons should be a health concern for human health, because this serovar has been isolated from the case of food poisoning in Japan [9]. The risk of secondary infection with Salmonella spp. can be reduced by removing piles of pigeon feces. In the present study, MAC strains were isolated from pigeon feces obtained from Kanagawa, Gifu, Aichi and Osaka Prefectures. MAC can cause disease in humans and other animals $[4,13]$ and dry dust from pigeon feces contaminated with such strains in public places might be a source of infection for birds and humans. 
We detected C. psittaci in all prefectures examined in the present study. The isolation frequency of this organism in fecal samples from the same public park or railroad station differed even when the sampling sites were very close (data not shown). These results suggest that C. psittaci infection of pigeons is rare or arises only as a result of very close contact, for example, in nests where the risk of infection with various fecal pathogens increases. The present results suggest that pigeon feces represent a source of several zoonotic agents. We believe that continuous surveys can estimate, and thus help to minimize the risk of humans contracting diseases from pigeons.

ACKNOWLEDGMENTS. We wish to thank Dr. H Fukushi of Gifu University for providing helpful guidance regarding detection of Chlamydia. We also wish to thank the Japan Anti-Tuberculosis Association, for examining samples for Mycobacteria.

\section{REFERENCES}

1. Abd El-Aziz, A.S., Elmossalami, M.K. and El-Neklawy, E. 2002. Nahrung 46: 51-53.

2. Casanovas, L., de Simon, M., Ferrer, D.M., Arques, J. and Monzon, G. 1995. J. Appl. Bacteriol. 78: 11-13.

3. Chiba, N., Arikawa, J., Takashima, I. and Hashimoto, N. 1984. Jpn. J. Vet. Sci. 46: 243-245.

4. Falkinham, J.O. 2002. Clin. Chest. Med. 23: 529-551.

5. Fukata, T., Uemura, T., Baba, E., Horiuchi, S. and Arakawa, A.
1986. Br. Vet. J. 142: 291-293.

6. Fukushi, H., Itoh, K., Ogawa, Y., Hayashi, Y., Kuzuya, M., Hirai, K. and Shimakura, S. 1983. Jpn. J. Vet. Sci. 45: 847848.

7. Haag-Wackernagel, D. and Moch, H. 2004. J. Infect. 48: $307-$ 313.

8. Hirai, K., Itoh, K., Yamashita, T., Fukushi, H., Hayashi, Y., Kuzuya, M., Shimakura, S., Hashimoto, A. and Akiyama, K. 1983. Jpn. J. Vet. Sci. 45: 843-845.

9. Matsushita, S., Kawamura, M., Takahashi, M., Yokoyama, K., Konishi, N., Yanagawa, Y., Kai, A., Yamada, S. and Morozumi, S. 2001. J. Jpn. Assoc. Inf. Dis. 75: 116-123.

10. Morita, Y., Arai, M., Nomura, O., Maruyama, S. and Katsube, Y. 1994. J. Vet. Med. Sci. 56: 585-587.

11. Morita, Y., Maruyama, S., Katsube, Y., Fujita, M., Yokoyama, E., Inoue, M. and Tsukahara, T. 1997. J. Jpn. Vet. Med. Assoc. 50: 407-410 (in Japanese with English summary).

12. Pasmans, F., Immerseel, F.V., Hermans, K., Heyndrikx, M., Collard, J., Ducatelle, R. and Haesebrouck, F. 2004. J. Clin. Microbiol. 42: 2000-2002.

13. Primm, T.P., Lucero, C.A. and Falkinham, J.O. 2004. Clin. Microbiol. Rev. 17: 98-106.

14. Sato, G., Ishiguro, N., Asagi, M., Oka, C., Kawanishi, T. and Inoue, T. 1977. Jpn. J. Vet. Sci. 39: 609-117.

15. Sawa, H. and Hirai, K. 1981. J. Jpn. Vet. Sci. 43: 277-279.

16. Shirai, K., Kabasawa, Y., Eguti, A. and Goto, K. 1998. J. Jpn. Vet. Med. Assoc. 51: 373-375 (in Japanese with English summary).

17. Springer, B., Stockman, L., Teschner, K., Roberts, G.D. and Bottger, E, C. 1995. J. Clin. Microbiol. 34: 296-303. 